\title{
Entrepreneurial firms in traditional industries. Does innovation matter for international growth?
}

\author{
Valerio Veglio • Antonella Zucchella
}

Published online: 27 March 2015

(C) Springer Science+Business Media New York 2015

\begin{abstract}
This research analyzes the impact of innovation in the internationalization process of small-medium enterprises in traditional Italian industries. Particular attention is paid to the role played by the typologies and sources of innovation in export performance, in order to detect which innovation drivers mostly impact on the export activity of Italian traditional small-medium enterprises. An exploratory investigation followed by an inferential analysis based on a sample of small and medium enterprises is developed in this study. The analysis highlights the positive impact of design
\end{abstract}

\footnotetext{
Summary Highlights

Contributions: This study analyses the role played by the typologies and sources of innovation in driving export performance in the case of smaller firms in traditional industries.

Research Hypothesis/Purpose: The internationalization of SMEs in traditional industries is positively related to innovation outputs represented by product design. Among the sources of innovation, informal and external sources are positively related to internationalisation.

Results/Findings: Through a multiple linear regression analysis on 162 SMEs, we found that product design is the main innovation driver that positively impacts on the export activity of SMEs. The usual sources of innovation, which characterise more dynamic industries, are not relevant in the internationalization of SMEs in traditional industries. External and informal sources of innovation -that we thought could matter- are not a significant source of innovation.

Limitations: We need to achieve a better understanding about the innovation model of smaller firms in traditional industries.

Theoretical Implications and Recommendations: The research contributes to literature in highlighting the issue of SMEs in traditional industries, which have been partially neglected by International Business and International Entrepreneurship studies.

Practical Implications and Recommendations: This study highlights the growth potential in foreign markets of small traditional firms, provided they acknowledge the importance of innovation and the need to pursue a more structured approach to innovation.
}

V. Veglio $(\bowtie)$

Institute of Management, Centre for Organizational Research (CORe), Università della Svizzera Italiana, Via Lambertenghi 10A, 6900 Lugano, Switzerland

e-mail: valerio.veglio@usi.ch

\section{A. Zucchella}

Department of Economics and Management, University of Pavia, Via San Felice, 5, 27100 Pavia, PV, Italy 
innovation for these firms in their internationalization process, while other typologies of innovation do not play a significant role. Among the sources of innovation, our findings highlight important differences with literature findings for other types of firms. For example, among external sources of innovation, both formal and informal partnerships are not significant. This is also holds for some internal sources, like research and development, which usually play a major role in other firms. The findings seem to suggest that small firms in traditional industries follow different innovation logics in relation to their international growth opportunities.

Abstrakt Diese Forschungsarbeit analysiert den Einfluss von Innovationen innerhalb des Internationalisierungsprozess von kleineren und mittleren unternehmen in traditionellen italienischen Industriesektoren. Besondere Beachtung kommt der Rolle $\mathrm{zu}$, die verschiedene Typologien und Innovationsquellen für die Exportleistungsfähigkeit spielen, um so wichtige Innovationstreiber für die Exportaktivitäten der traditionellen italienischen kleineren und mittleren unternehmen s zu bestimmen. Analyse basierend auf einer Stichprobe von 162 kleineren und mittleren unternehmen wird für diese Studie angewandt. Die Ergebnisse dieser Analyse betonen den positiven Einfluss von „DesignInnovationen“ innerhalb des Internationalisierungsprozesses dieser Firmen, während andere Innovationstypologien keine signifikanten Effekte aufweisen. Hinsichtlich den untersuchten Innovationsquellen konnte keine Hypothese aus der gängigen Literatur bestätigt werden. Im Gegenteil, bezüglich den externen Innovationsquellen sind sowohl formelle als auch informelle Partnerschaften nicht signifikant. Dies trifft im besonderen Masse für interne Innovationsquellen, wie beispielsweise Forschungs- und Entwicklungsaktivitäten, zu. Die Erkenntnisse deuten darauf hin, dass kleine Unternehmen in den traditionellen Industrien einen eigenständigen Innovationspfad verfolgen, um ihre internationale Wachstumsmöglichkeiten zu erreichen.

Keywords Small-medium enterprises · Innovation · Design innovation ·

International business and international entrepreneurship

\section{Introduction}

Entrepreneurial firms are characterized by proactivity, innovativeness and willingness to take risks (Covin and Slevin 1991; Covin and Miller 2014). Small- and mediumsized enterprises oriented to grow in foreign markets tend to show these traits. Many studies have focused on young firms and high tech international ventures as cases of international entrepreneurship. However, small and mature firms in traditional industries may as well represent a very interesting field for research in international entrepreneurship, from different perspectives. First, these firms, especially when they are located in developed economies, are challenged by the growing competition from lower cost manufacturers of the developing and the emerging economies. This implies that internationalization can be a more uncertain and challenging growth option. Secondly, the global competition should drive these firms towards innovation, given the difficulty in competing on cost, while outsourcing/offshoring production is uncommon in smaller companies. 
In order to achieve competitiveness in international markets, smaller firms need to develop unique firm-specific assets. Innovation represents one of the main avenues to the building of firm-specific advantages. For smaller firms, the internationalization process is in itself an expression of innovation and represents an entrepreneurial decision that carries relevant uncertainties for firms which are both subject to the liability of foreignness and smallness (Dimitratos et al. 2003). These uncertainties are counterbalanced by opportunities embedded in foreign markets (Etemad and Wright 2001). The literature suggests that the likelihood of capturing these opportunities effectively may depend on the international marketing of a firm's innovations: in this way, it is possible to build uniqueness in the company's offer.

There is a number of studies on the relationship between innovation and internationalization, but they mostly refer to large companies and they predominantly focus on hightechnology and knowledge-intensive industries (Pla-Barber and Alegre 2007; Onetti et al. 2012). This research aims at highlighting the role of innovation in the internationalization process of small firms in traditional industries, a field in which different authors have outlined a research gap (Bell et al. 2003; Zucchella and Siano 2014). This research addresses the specificities of the innovation processes taking place in small- and medium-sized firms (SMEs) in traditional industries. In particular, it highlights a typology of innovation, which is likely to characterize these firms, namely design innovation (Alcaide-Marzal and Tortajada-Esparza 2007). It is likely that the capacity to develop innovations in product design in textiles, leather, apparel and furniture can better support domestic and international growth. The research also aims at uncovering specificities in the sources of innovation, when foreign market growth is pursued.

Traditional industries show a scarce internal R\&D activity and are highly fragmented because they are dominated by small players. These industries range from textiles to apparel, to leather and to furniture (Pavitt 1984; Spithoven et al. 2009). Their competitiveness rests on the capacity to follow or anticipate market trends, on design capabilities and on intangible sources of competitiveness like branding and "made in" effects. The entrepreneurs and the top management team frequently coincide and have a crucial role in developing the above-mentioned leverages of competitive advantage (Zucchella and Siano 2014).

This topic is particularly relevant for managers, entrepreneurs and policymakers, who need to develop awareness about how innovation can contribute to small firms' international competitiveness. The issue is particularly relevant for mature economies like Italy, characterized by a predominance of traditional industries and by a very slow economic growth. In these countries, small firms represent large part of the industrial system and they are increasingly pressured by global competition. Innovation can be a major path towards a stronger global competitive advantage. It is also likely that in these firms, innovation processes have different characteristics than in other industries and in larger firms (Spithoven et al. 2009).

This article develops some research hypotheses based on a literature review and-in the empirical section - tests these hypotheses on a sample of small- and medium-sized Italian firms, all belonging to traditional industries. The discussion about the findings highlights the specific nature of innovation processes in small firms in traditional industries and supports the link between the former and the international growth of these firms. It also shows that a better awareness about this role of innovation in driving 
growth and global competitiveness may help managers and policymakers in developing more effective and better targeted innovation policies.

\section{Literature and hypotheses development}

This research fits in a resources-based frame as applied in international business studies (Peng 2001). Innovation is acknowledged as a means for building uniqueness in the resources and capabilities base (O'Cass and Weerawardena 2009).

\section{Innovation and internationalization in SMEs}

The intersection of internationalization and innovation is at the heart of international entrepreneurship (Onetti et al. 2012). Andersen and Kheam (1998) suggest that internationalization is in itself a process of innovation, following Schumpeter (1934). Product, process and managerial innovations can support international growth; at the same time, the exposure to foreign markets enhances learning opportunities and feeds back innovation to start a new cycle.

It is widely recognized in international business and export management literature that small firms are poorer in managerial and financial resources, and these resource shortages affect their propensity to internationalize as well as their success in international markets. These disadvantages can be offset by the presence of unique resources, which enable the firm to achieve competitiveness in foreign countries. The ownership of innovative resources and capabilities is widely recognized as a major driver of firm growth both domestically and abroad (Pla-Barber and Alegre 2007; Kafouros et al. 2008). A more sophisticated knowledge base lies at the heart of the early and fast internationalization of small ventures (Bell et al. 2003). The literature acknowledges great importance to innovation, in order to explain SME internationalization (Schoonhoven et al. 1990; Onetti et al. 2012). The case of SMEs in traditional industries is more controversial: the few studies in this field highlight a more reactive approach to international growth and a lesser propensity to develop innovations to conquer foreign markets (Bell et al. 2003). While firms in more dynamic industries, like high technology, tend to rely on internal R\&D and research partnerships in order to develop new products and new processes, firms in traditional industries (and especially the smallest ones) show a different innovation process, and the links between innovation and internationalization tend to be less clear (Zucchella and Siano 2014). In these firms, the innovation processes tend to be less visible, less accountable and mostly "embedded" in continuous improvements in product and production technology. Innovations in product design are likely to be very important, especially in traditional industries like apparel and textiles, leather and furniture, where the aesthetic content is key to achieve market success. Italian traditional SMEs are usually positioned in global market niches, and the mentioned processes of innovation are stimulated by the need to adjust their production to the demands of global customers (Zucchella and Palamara 2007). They also benefit of a country of origin effect and this further enhances the role of product design in foreign market growth.

Regarding the typologies of innovation, which mostly affect international performance, Basile (2001) finds out for Italian firms a relationship between product 
innovation and exporting. Cassiman and Golovko (2011) find a positive relationship between product innovation, productivity and export performance. Pla-Barber and Alegre (2007) discuss how technological capabilities enhance export performance. It is still unclear, however, the nature of the relationship between innovation and internationalization in low-tech industries and notably in the case of small firms in traditional industries. There is also a research gap in considering typologies of innovation outputs alternative to the usual product or process innovation categories. Some authors suggest that innovation outputs in traditional industries are substantially different and require differentiated measures, like for example aesthetic ones (Alcaide-Marzal and Tortajada-Esparza 2007). Traditional industries (like textiles, apparel, clothing, footwear, furniture) tend to compete primarily, though not exclusively, on design innovations (Pesendorfer 1995; Hansen and Serin 1997).

The above considerations lead us to formulate the following hypotheses:

H1: The internationalization of small traditional firms is positively related to innovations outputs. The relationship should be particularly significant for product design innovations.

The sources of innovation

Among the different sources of innovation, we can establish a distinction between internal and external sources and between formal and informal sources. The internal sources include the internal R\&D projects, while the external sources may be represented by the acquisition of new knowledge through the purchase of licenses or consulting services (Veugelers and Cassiman 1999). External sources also include formal and informal partnerships. An example of formal partnerships is a research and/or development joint venture or a non-equity agreement. The informal links can include membership in a local district or cluster, a strong and collaborative relationship with key customers or with some research agency or public institution.

Smaller firms are subject to relevant resources constraints and thus may find obstacles in obtaining the necessary financial and managerial resources to organize an internal R\&D activity. In addition to the resources constraint hypothesis, small firms in traditional industries experience innovation processes, which are more embedded in manufacturing and design activities and incremental. As such, they are not clearly reported as R\&D activity. Some studies on Italian small firms highlight that R\&D in Italian firms is lower than in comparable systems, and even lower in traditional industries and smaller firms (Foresti 2005).

In addition to this, there are findings evidencing that small traditional firms do not frequently access to new knowledge via the acquisition of licenses or the use of consulting services (Sterlacchini 2008). This is again due not only to resources constraints but also to the difficulty in perceiving and valuing (pricing) the contribution of new knowledge in these small and mature industrial companies.

Fernhaber et al. (2009), in dealing with international knowledge as a key intangible resource for international growth, highlight the problem of accessing to knowledge, given the liabilities of newness and foreignness. In their study, they investigate both internal and external sources of international knowledge for 206 new ventures. The 
findings suggest international knowledge may be sourced externally, including from alliance partners, venture capital firms and firms in close proximity. We think that in SMEs, the access to external knowledge is prevailing also in the case of knowledge relevant for innovations.

Partnerships addressed to research and innovation can be particularly relevant for hightech companies: these collaborations serve for a number of purposes, including accelerated international growth (Coviello and Munro 1997; Chetty and Stangl 2010). However, the literature about small mature firms in traditional industries is very scarce. We can hypothesize that some of these collaborations, especially with universities, technological parks, etc. are not very common, for the same reasons we mentioned above about the limited role of internal R\&D (Foresti 2005). On the other hand, collaborations with some key suppliers or customers may constitute a carrier of innovation in these firms, also when these relationships do not involve any research and innovation activity. In fact, these collaborations are rich in information, which may also indirectly stimulate innovations. An additional source of new knowledge is represented by machinery and technology purchased by suppliers. Small traditional firms can thus rely on informal sources of information through which innovation is supported and international growth is enabled. These informal sources may be represented by non-formalized partnerships and relationships with other firms and customers (Bonte and Keilback 1995).

Many small firms, both in high-tech and in traditional industries, belong to geographical clusters. In Italy, the role of clusters and industrial districts is well acknowledged and provides an informal system of ties (Becchetti and Rossi 2000). In local clusters, firms can access relevant information for innovation (Bathelt et al. 2004) and any other occasion for meeting competitors and customers, as for example trade fairs. Some studies highlight the strategic role of trade fairs in establishing contacts and providing a fertile ground for network development for smaller firms (Evers and Knight 2008). The literature on innovation has portrayed trade fairs as "temporary clusters" (Bathelt and Schuldt 2008), where firms can access to relevant information on competitors and customers. Based on the above analysis, we can formulate the following hypothesis.

$\mathrm{H} 2$ : The internationalization of small traditional firms rests predominantly on informal and external sources of innovation.

\section{Data and methodology}

In order to test the hypotheses, this research adopts a questionnaire already developed and tested in a different research setting, the textile and apparel in Campania region (TA-CAMP) research project (ISMO, special issue 2014). The questionnaire has been submitted to a population of exporting SMEs in traditional Italian industries, as defined by the National Institute of Statistics. The questionnaire contains information related to the relationship between SME export activity and innovation. In particular, the survey is divided in the following sections: general demographic information of SMEs, internationalization process, real and financial services for internationalization and innovation drivers for internationalization. The variables that refer to innovation are divided in the following sections: sources of information for innovation, types of innovations introduced in the last 4 years, effectiveness of drivers of the main drivers 
Table 1 Distribution of the Italian traditional industries compared to our sample of SMEs

Traditional industries

Percentage distribution of firms in

Percentage in our sample (\%) Italy (traditional industries $=100)(\%)$

\begin{tabular}{lll}
\hline Textile, apparel and fashion clothing & 42 & 47 \\
Furniture & 26 & 28 \\
Leather & 21 & 15 \\
Others & 11 & 10 \\
\hline
\end{tabular}

Our estimates based on ISTAT (National Bureau of Statistics) for the first column and our sample distribution in the second column

of innovation and obstacles to innovation. The innovation-related variables were expressed both on seven-point Likert scales and in a dichotomous form. The performance indicator is export intensity and it is expressed in five classes. A qualitative control was made on the available data in order to highlight variables, which are not suitable for the analysis (Giudici 2009). It was also conducted a formal check on the content of the variables and on the possible presence of missing or incorrect data. The firms that did not answer to the questionnaire submitted were removed from the database studied, to obtain a significant sample for the analysis.

The questionnaire was sent to 1,000 SMEs from the database of the Italian Chambers of Commerce of active exporters, all belonging to traditional industries (such as textiles, apparel, furniture and leather), and it refers to the year 2012. The surveyed firms are mostly concentrated in sectors, where the "Made in Italy" has achieved important international recognition and where the small size prevails. Table 1 shows the percentage distribution of firms belonging to these industries in Italy, in comparison to our sample.

We obtained 162 valid questionnaires, with a return rate of $16,2 \%$, which was considered acceptable for this kind of studies (Baruch 1999; Harzing et al. 2011).

A cross-sectional design and a data mining methodology were used to accomplish the research goals (Cooper and Schindler 2005). The whole database was composed of 28 quantitative variables. The target variable is quantitative in nature and concerns the "export intensity" of the firms. This variable provides the percentage of the export activities on the turnover of the companies. Export intensity is, by far, the most common export performance measure in empirical research (Katiskeas et al. 2000; Sousa et al. 2008a, b).

Due to the nature of the data available, we decided to divide the data analysis in two steps: descriptive and inferential. First, we performed the Pearson correlation analysis (PCA) in order to measure both strength and direction of the linear relationship between the export intensity and each innovation without identifying causes and effects (Ahlgren et al. 2003). We estimated the Pearson correlation coefficient (PCC) between the export intensity (dependent variable) and each innovation driver (independent variables). In addition, we added in the PCA the variable related to the classes of turnover of companies as well as the variable that concerns the number of employees. The latter variables could provide significant information in analyzing the relationship between companies' internationalization and innovation. In the second step, we ran a multiple linear regression based on the stepwise method in order to discover which innovation drivers impact on the export intensity of Italian traditional SMEs. We decided to include in the predictive model the same variables used for the PCA to 
discover regularities or relations that are at first unknown with the aim of obtaining clear and useful results for our research (Veglio 2013; Giudici 2009). According to Anderson et al. (2010), the predictive value of each innovation driver is estimated through the following equation:

$$
y=a+b_{1}+b_{2}+b_{3}+\ldots . .+b_{27}+e_{i}
$$

Where:

$a$ the intercept of the regression function

$b$ the regression coefficient

$e_{i}$ the random error of the regression function related to the $i$ observations

The adjusted $R$-square confirms the goodness of the predictive model previously implemented in this research (Tan et al. 2006).

\section{Empirical findings}

Table 2 shows that $37 \%$ of international companies have a ratio of export to turnover (export intensity) in the range 5-25\%, while only 5\% of firms have a high percentage of the export intensity. Thirty-six percent of firms declare only occasional or marginal exporting activity $(0-5 \%)$. This result reveals a huge unexploited potential for foreign growth. In fact, firms in traditional industries, which are subject to a positive made in effect on foreign markets, should show higher levels of internationalization. This has been connected to lack of resources and, more specifically in relation to the objective of our research, to a limited innovation effort (Calof 1994). In addition, Table 3 demonstrates the number of international companies that invested in new product design in the previous 4 years. SMEs with a high ratio of export in relation to firms' turnover $(31 \%)$ invest more in new product designs than SMEs with a low ratio of export intensity (14\%). Table 4 shows the distribution of the employment level within firms and confirms that firms in these Italian industries are predominantly small or very small. Ninety-four percent of firms have fewer than 50 employees, and only $6 \%$ of firms have a number of employees ranging from 50 to 249 (medium-sized firms according to European Union parameters). Size has been considered in many studies as an acceptable proxy for the resources endowment of a firm (Calof 1994), affecting the capacity of a firm to enter foreign markets. In order to better understand the relationships among the studied variables, both size- and innovation-related ones, we made a correlation analysis followed by a multiple linear regression based on the stepwise method, as mentioned above.

Table 2 Export intensity classes 
Table 3 Percentage of export intensity on new product design

\begin{tabular}{lcr}
\hline & New product design & \\
\hline Export intensity & Yes & No \\
$76-100$ & 51 & 9 \\
$51-75$ & 21 & 2 \\
$26-50$ & 10 & 3 \\
$5-25$ & 6 & 2 \\
$0-5$ & 36 & 22
\end{tabular}

Table 5 shows the PCC between the target variable (export intensity) and the independent variables related to either the size or the innovation drivers. From the analysis, it emerges that the statistically significant correlations are a few, notwithstanding the number of variables analyzed. Size apparently does not play a role in supporting foreign growth: on the contrary, size as measured by turnover is negatively related to export performance. This finding is contrast with the above-mentioned literature, but is supported by other studies (Bonaccorsi 1992).

Italian SMEs consider the participation to trade fairs an opportunity to obtain information related to innovation, but on the other hand, they do not think this supports their own innovation processes effectively in order to gain global competitiveness. It is quite puzzling to observe opposite and significant correlations about the same variable. However, as we mentioned, in the first case (positive correlation), firms think that these events are sources of inspiration for innovation, but in the effective implementation of new products, new design, etc. to achieve foreign growth, other variables matter. Also, the role of funding and internal R\&D is negatively related to export intensity. This may be explained by the nature of the innovations that these firms have introduced in the last 4 years and how they have contributed to export performance. Small firms in traditional industries mostly realize "soft" innovations in terms of product design, use of new materials (especially in textile) and management methods, and these types of innovation drive foreign growth. The development of new product or process technologies, involving internal R\&D and more financial resources, is uncommon in these firms. Information from research institutions is positively related to export performance and mostly refers with the above-mentioned typologies of innovation. Particularly significant is the relationship between export intensity and new product design, a finding that is coherent with the mentioned literature highlighting the specificities of these industries. Among the obstacles to innovation, aspects such as operative risk, difficulty to change industrial processes, difficulty of corporate reorganizations, lack of adequate

Table 4 Analysis of the employment-level variable 
Table 5 Person correlation analyses

Target variable $(Y) \quad$ Independent variables $(X)$

Pearson correlation coefficient

\begin{tabular}{|c|c|c|}
\hline Export intensity & Export intensity & 1 \\
\hline Export intensity & Classes of turnover & $-0.25^{* *}$ \\
\hline Export intensity & Number of employees & 0.06 \\
\hline \multicolumn{3}{|c|}{ Sources of information for innovation } \\
\hline Export intensity & Trade fairs & $0.24^{* *}$ \\
\hline Export intensity & Suppliers of machinery and technology & -0.13 \\
\hline Export intensity & Location in an industrial district & 0.02 \\
\hline Export intensity & Location in different clusters & 0.12 \\
\hline Export intensity & Customers & -0.02 \\
\hline Export intensity & Business partnerships & 0.01 \\
\hline Export intensity & Licenses acquisitions & 0.1 \\
\hline Export intensity & Research institutions and universities & $0.16^{*}$ \\
\hline Export intensity & Science parks & 0.15 \\
\hline Export intensity & Consultants & 0 \\
\hline Export intensity & Internal R\&D & 0.12 \\
\hline \multicolumn{3}{|c|}{ Types of innovations introduced in the previous 4 years } \\
\hline Export intensity & New materials & $0.17^{*}$ \\
\hline Export intensity & New product design & $0.25^{* *}$ \\
\hline Export intensity & New production technologies & -0.03 \\
\hline Export intensity & New management methods & $0.22^{* *}$ \\
\hline \multicolumn{3}{|c|}{ Effectiveness of drivers of innovation } \\
\hline Export intensity & Investments and funding & $-0.18^{*}$ \\
\hline Export intensity & R\&D within the firm & $-0.16^{*}$ \\
\hline Export intensity & Collaborations with suppliers, customers, firms and institutions & -0.1 \\
\hline Export intensity & Participation to fairs & $-0.27^{* *}$ \\
\hline \multicolumn{3}{|c|}{ Obstacles to innovation } \\
\hline Export intensity & Operative risk is too high & -0.03 \\
\hline Export intensity & Industrial processes are difficult to change & 0 \\
\hline Export intensity & Difficulty of corporate reorganizations & 0.02 \\
\hline Export intensity & Lack of adequate financial instruments & 0.05 \\
\hline Export intensity & Lack of sources funding and services & 0.09 \\
\hline Export intensity & Difficulty of finding qualified staff & -0.01 \\
\hline
\end{tabular}

$* * 0.01$ level of significance for correlation; $* 0.05$ level of significance for correlation

financial instruments and services and difficulty of finding qualified staff have not affected significantly the SMEs export performance.

In the second part of the empirical analysis, a multiple linear regression model based on a stepwise method is used to better understand the strength and sign of the mentioned relationships. Table 6 shows the result of multiple linear regression models between the export intensity activity of SMEs and the independent variables related to 
Table 6 Multiple linear regression models: coefficients and goodness of fit

\begin{tabular}{lllll}
\hline Dependent variable & Independent variables & Estimate value & Significance level* & $\begin{array}{l}\text { Validity of the model: } \\
\text { adjusted } R \text {-square }\end{array}$ \\
\hline Export intensity & Participation to fairs & -0.26 & 0.00 & 0.20 \\
& Classes of turnover & -0.30 & 0.00 & 0.03 \\
& New product design & 0.17 & 0.03 & \\
& Number of employees & 0.17 & &
\end{tabular}

Number of observations $=162$

$*<0.05$ significance level

either the size or the innovation drivers. The table shows only the variables that are statistically significant for our research. The model highlights that hypothesis 1 (design innovations contribute to export performance) is confirmed, while hypothesis 2 (external and informal sources of innovation contribute to export performance) finds no support.

\section{Discussion}

Product design is the main innovation driver that positively impacts on the export activity of SMEs. The Italian traditional SME innovation process is thus mostly embedded in continuous improvements in new products design. These SMEs focus on new product design in order to anticipate market trends. The aesthetic content of products in industries like textiles, apparel, furniture and leather makes the design activity particularly relevant for global competitiveness. Smaller firms can develop these innovations without committing relevant resources and leveraging mostly on the creativity of their entrepreneurs and employees. These companies survive in a highly competitive landscape, confronted on one side by low cost productions from emerging markets and on the other side by global luxury brands, also thanks to other factors, like cost control and exploitation of the made in effect. Our starting hypotheses were that in small firms belonging to traditional industries, the innovation outcomes could be mainly related to design innovations and that the innovation pipeline should be nurtured by external and informal sources. The first hypothesis is verified, because innovations in product design are the only significant variable among the different forms of innovation output. This finding indicates that innovations in product design are significant if the firms want to achieve a higher internationalization. This is coherent with the nature of these businesses (e.g. textile, apparel, furniture). On the other hand, the usual sources of innovation, which characterize more dynamic industries, like formal internal $R \& D$ and research partnerships, are not relevant. External and informal sources of innovation that we thought could matter, like customers and districts, are not acknowledged by firms as a significant source of innovation. It seems that in traditional industries, innovations driven by adapting to customer needs or imitating other firms are not conducive to global competitiveness. The effectiveness of global growth in highly competitive and traditional industries needs to rest on doing things which are substantially different than what competitors do. This also explains the ambiguous role of trade fairs: we know from a number of surveys that 
participation to trade fairs for these firms is a very common way to access to foreign market opportunities (Julien and Ramangalahy 2003).

The PCA provided a positive correlation between export intensity and information obtained during trade fairs for innovation. On the contrary, the correlation between the effective impacts of trade fairs in developing innovations was negative. In the regression analysis, the first outcome is not statistically significant unlike the second that is significant. A possible interpretation is that for these firms, trade fairs are primarily a way to achieve visibility and establish commercial contacts. They are also an occasion to monitor competitors and spot industry trends, but this activity does not influence design innovation and export performance. On the contrary, this information permits to innovate in opposite directions than competitors. Trade fairs are ways of observing innovations from other firms, but this information is not conveyed to developing similar products. Instead, it is a stimulus for differentiated strategic moves and product design. The international performance of these companies reflects their ability in creating market niches and in differentiating their offer from competitors, with particular attention on both uniqueness and quality of the products offered to customers. An alternative or complementary explanation for the negative impact of trade fairs as innovation drivers on export performance, the participation to trade fairs could divert human and financial resources from a more effective innovation pipeline.

The ambiguous role of size on export performance partially confirms that these firms are affected by resources constraints and trade-offs in the use of resources. The number of employees is positively related to export performance, though the opposite is true for size as measured by revenues. Companies with adequate staff can manage better their international operations. At the same time, revenues are negatively related to export performance. This can be explained by the presence of smaller firms, which are highly specialized in very narrow market niches, where they achieve excellent export performances (Zucchella and Palamara 2007).

\section{Conclusions}

Innovation is a driver for the process of internationalization of SMEs in traditional industries and, notably, design innovation. On the other hand, this research outlines a high percentage of firms, which do not exploit fully the potential of international markets (showing low and marginal or occasional export activity) probably because of the lack of awareness of the factors driving international success.

This research also suggests that the innovation model of smaller traditional firms and its impact on internationalization is difficult to capture. Many results evidenced in literature do not hold for this type of firms. This does not necessarily imply a lack of relevance of innovation in these firms (as the findings about design innovation suggest), but - instead - the need of developing a different and deeper understanding of how innovation occurs in traditional SMEs. In fact, while the only valid empirical evidence refers to design innovation, it is likely that other forms of innovation exist in these firms, mostly embedded in incremental improvements in products and processes, and are very difficult to measure. The need to differentiate from competitors leads these firms to rely mostly on their own creativity resources, and not on partnerships and collaborations. 
This work contributes to extant literature in highlighting the issue of small and mature firms in traditional industries, which have been partially neglected by international business and international entrepreneurship studies. These streams have mostly focused either on large multinationals or on fast growing knowledge intensive ventures.

This research also highlighted the role of constraints to innovation and the need for policymakers to address these constraints with appropriate actions. Policymaking could support the design innovation capacity through appropriate education of future employees and entrepreneurs. Formal ties between small firms and design schools could be promoted. International promotion of the made in, not only as a common standard feature of some products but also in its design innovation side, could help occasional exporters to face new challenges in foreign markets. Also, managers and entrepreneurs can benefit from these findings, because this research also highlights the growth potential in foreign markets of small traditional firms, provided they acknowledge the importance of innovation and the need to pursue a more structured approach to innovation, leveraging on multiple sources and uncovering the innovation potential in business relationships and in collaborations with research institutions. Our findings reveal that there is ample room for improving the international entrepreneurial processes in smaller firms in traditional industries. In many of these firms, the export potential is underexploited. Notwithstanding the resources constraints, a number of small firms can achieve substantial foreign sales intensity, thanks to their capacity to focus on global market niches. In traditional industries, global niche leadership can be pursued through the ability to leverage on the made in effect on one side and to reinterpret this effect with firm creativity and design on the other side.

A future research direction is represented by the need to develop a better understanding about how innovation occurs in these firms, which is their innovation model, if any, and how it affects global growth. This contribution also shows that in the universe of internationally oriented SMEs, there are different typologies of internationalization and innovation models. Finally, from a methodology perspective, this study could be integrated through the development of in-depth interviews to entrepreneurs in order to better grasp a broader spectrum of data related to the relationship between internationalization and innovation of SMEs in traditional Italian industries.

\section{References}

Ahlgren P, Jarneving B, Rousseau R (2003) Requirement for a cocitation similarity measure, with special reference to Pearson's correlation coefficient. J Am Soc Inf Sci Technol 54(6):550-60

Alcaide-Marzal J, Tortajada-Esparza E (2007) Innovation assessment in traditional industries. A proposal of aesthetic innovation indicators. Scientometrics 72(1):33-57

Andersen O, Kheam LS (1998) Resource-based theory and international growth strategies: an exploratory study. Int Bus Rev 7(2):163-184

Anderson DR, Sweeney DJ, Williams PA, Freeman J, Shoesmith E (2010) Statistic for business and economics. South-Western, Hampshire

Baruch Y (1999) Response rate in academic studies — a comparative analysis. Hum Relat 52(4):421-438

Basile R (2001) Export behaviour of Italian manufacturing firms over the nineties: the role of innovation. Res Policy 30(8):1185-1201

Bathelt H, Schuldt N (2008) Between luminaires and meat grinders: international trade fairs as temporary clusters. Reg Stud 42(6):29-41 
Bathelt H, Malmberg A, Maskell P (2004) Clusters and knowledge: local buzz, global pipelines and the process of knowledge creation. Hum Geogr 28(1):31-56

Becchetti L, Rossi SPS (2000) The positive effect of industrial district on the export performance of Italian firms. Rev Ind Organ 16(1):53-68

Bell J, McNaughton R, Young S, Crick D (2003) Towards and integrative model of small firm internationalisation. J Int Entrep 1:339-362

Bonaccorsi A (1992) On the relationship between firm size and export intensity. J Int Bus Stud 605-635

Bonte W, Keilback M (1995) Concubinage or marriage? Informal and formal cooperations for innovation. Int J Ind Organ 23(3-4):279-302

Calof JL (1994) The relationship between firm size and export behavior revisited. J Int Bus Stud 367-387

Cassiman B, Golovko E (2011) Innovation and internationalization through exports. J Int Bus Stud 42(1):56-75

Chetty SK, Stangl LM (2010) Internationalization and innovation in a network relationship context. Eur J Mark 44(11-12):1725-1743

Cooper DR, Schindler P (2005) Business research methods. McGraw-Hill, Berkshire

Coviello N, Munro H (1997) Network relationships and the internationalisation process of small software firms. Int Bus Rev 6(4):361-386

Covin JG, Miller D (2014) International entrepreneurial orientation: conceptual considerations, research themes, measurement issues, and future directions. Entrep Theory Pract 38(1):11-44

Covin JG, Slevin DP (1991) A conceptual model of entrepreneurship as firm behaviour. Entrep Theory and Pract 7-25

Dimitratos P, Johnson J, Slow J, Young S (2003) Micromultinationals: new types of firms for the global competitive landscape. Eur Manage J 21(2):164-174

Etemad H, Wright R (2001) SMEs and the global economy. J Int Manage 7(3):151-154

Evers N, Knight G (2008) Role of international trade shows in small firm internationalization: a network perspective. Int Mark Rev 25(5):544-562

Fernhaber SA, McDougall-Covin PP, Shepherd DA (2009) International entrepreneurship: leveraging internal and external knowledge sources. Strateg Entrep J 3:297-320. doi:10.1002/sej.76

Foresti G (2005) Specializzazione produttiva e struttura dimensionale delle imprese: come spiegare la limitata attività di ricerca dell'industria italiana. Riv Politica Econ XCV 3(4):81-122

Giudici P (2009) Applied data mining. Metodi informatici, statistici e applicazioni. McGraw-Hill, Milano

Hansen PG, Serin G (1997) Will low technology products disappear? The hidden innovation processes in low technology industries. Technol Forecast Soc Chang 55(2-7):179-191

Harzing AW, Reiche BS, Pudelko M (2011) Challenges in international survey research: a review with illustration and suggested solutions for best practice. Eur J Int Manag 7(1):112-134

Julien PA, Ramangalahy C (2003) Competitive strategy and performance of exporting SMEs: an empirical investigation of the impact of their export information search and competencies. Entrep Theory Pract. Springer 227-245

Kafouros M, Buckley P, Sharp J, Wang C (2008) The role of internationalization in explaining innovation performance. Technovation 28(1-2):63-74

Katiskeas K, Leonidou L, Morgan N (2000) Firm-level export performance assessment: review, evaluation, and development. J Acad Mark Sci 28(4):493-511

O'Cass AG, Weerawardena J (2009) Examining the role of international entrepreneurship, innovation and international market performance in SME internationalization. Eur J Mark 43(11/12):1325-1348

Onetti A, Zucchella A, Jones M, McDougall P (2012) Guest editor's introduction to the special issue: entrepreneurship and strategic management in new technology based companies. J Manage Governance 16(3):5-22

Pavitt K (1984) Patterns of technological change: towards a taxonomy and theory. Res Policy 13:343373

Peng M (2001) The resource based view and international business. J Manage 27(2):803-829

Pesendorfer W (1995) Design innovation and fashion cycles. Am Econ Rev 85(4):771-792

Pla-Barber J, Alegre J (2007) Analysing the link between export intensity, innovation and firm size in a science-based industry. Int Bus Rev 16(3):275-293

Schoonhoven CB, Eisenhardt KM, Lymman K (1990) Speeding products to market: waiting time to first product introduction in new firms. Adm Sci Q 35:177-207

Schumpeter JA (1934) The theory of economic development. Harvard University Press, Cambridge

Sousa CMP, Martinez-Lopez FJ, Coelho F (2008a) The determinants of export performance: a review of the research in the literature between 1998 and 2005. Int J Manage Rev 10(4):343-374

Sousa C, Martinez-Lopez FJ, Coelho F (2008b) The determinants of export performance: a review of the research in the literature between 1998 and 2005. Int J Manage Rev 10(2):1-32 
Spithoven A, Clarysse B, Knockaert M (2009) Building absorptive capacity to organise inbound open innovation in low tech industries, Working papers of faculty of economics and business administration. Ghent University, Belgium

Sterlacchini A (2008) Economia della conoscenza e politiche regionali: considerazioni sul caso italiano. L'Industria 4:663-688

Tan PN, Steinbach M, Kumar V (2006) Introduction to data mining. Pearson Education, Boston

Veglio V (2013) Forecasting marketing performance via web data mining. LAP LAMBERT Academic Publishing, Saarbrücken

Veugelers R, Cassiman B (1999) Make and buy in innovation strategies: evidence from Belgian manufacturing firms. Res Policy 28:63-80

Zucchella A, Palamara G (2007) Niche strategy and export performance. Adv Int Mark 17(2):63-88

Zucchella A, Siano A (2014) Internationalization on innovation as resources for SME growth in foreign markets. a focus on textile and clothing firms in the Campania region. Int Stud Manage Organ 44(1):21-41 